\title{
Through the Eye of a Film Festival: Toward a Curatorial and Spectator- Centered Approach to the Study of African Screen Media
}

\author{
by LINDIWE DOVEY
}

M

ost scholarship on African screen media acknowledges outright that there have been, and continue to be, many trends and traditions in filmmaking across the continent and in the African diasporas, making it impossible to distinguish any particular coherence to the category of African filmmaking. Many scholars have advanced this argument through analysis of distinct production infrastructures, films, genres, nationally located cinemas, particular filmmakers, and critical concepts such as tradition and modernity. ${ }^{1}$ Furthermore, the rise of popular video-movie making in Ghana and Nigeria from the late 1980s onward, and the discussion and research that have grown around that practice, have compelled scholars of African screen media to pay far greater attention to the "different material conditions of creation, circulation, and consumption" of audiovisual cultural products. ${ }^{2}$ There has been relatively little

1 On production infrastructures, see, e.g., Manthia Diawara, African Cinema: Politics and Culture (Bloomington: Indiana University Press, 1992); Nwachukwu Frank Ukadike, Black African Cinema (Berkeley: University of California Press, 1994); Claire Andrade-Watkins, "France's Bureau of Cinema-Financial and Technical Assistance, 1961-1977: Operations and Implications for African Cinema," in African Experiences of Cinema, ed. Imruh Bakari and Mbye Cham (London: British Film Institute, 1996), 112-127; Alessandro Jedlowski, "Small Screen Cinema: Informality and Remediation in Nollywood," Television and New Media 13, no. 5 (2012): 431-446. On films, see, e.g., Françoise Pfaff, ed., Focus on African Films (Bloomington: Indiana University Press, 2004). On genres, see, e.g., Akinwumi Adesokan, Postcolonial Artists and Global Aesthetics (Bloomington: Indiana University Press, 2011); Lindsey Green-Simms, "Occult Melodramas: Spectral Affect and West African Video-Film," Camera Obscura 27, no. 280 (2012): 25-59. On nationally located cinemas, see, e.g., Paulin Soumanou Vieyra, Le cinéma au Sénégal (Brussels: OCIC; Paris: L'Harmattan, 1983); Jonathan Haynes, ed., Nigerian Video Films (Athens: Ohio University Press, 2000); Jacqueline Maingard, South African National Cinema (New York: Routledge, 2007); Carmela Garritano, African Video Movies and Global Desires: A Ghanaian History (Athens: Ohio University Press, 2013). On particular filmmakers, see, e.g., David Murphy and Patrick Williams, Postcolonial African Cinema: Ten Directors (Manchester, UK: Manchester University Press, 2007). For critical concepts, see, e.g., Jude Akudinobi, "Tradition/Modernity and the Discourse of African Cinema," in Critical Approaches to African Cinema Discourse, ed. Nwachukwu Frank Ukadike (Lanham, MD: Lexington Books, 2014), 47-60.

2 For a comprehensive literature overview, see Jonathan Haynes, "A Literature Review: Nigerian and Ghanaian Videos," Journal of African Cultural Studies 22, no. 1 (2010): 105-120. Also 
research, however, on the specific sites where films are screened, consumed, and interpreted: film festivals, multiplex cinemas, makeshift video halls, people's homes and courtyards, and internet cafés. The focus of my current research, and of this essay, is film festivals, both as global sites for the curation and reception of films by Africans and as sites within the African continent for the curation and reception of films from all over the world. ${ }^{3}$

One apparent typology (and chronology) for analysis would group film festivals that screen films by Africans as follows: African film festivals on the African continent (founded from the mid-1960s, such as FESPACO, the Pan-African Film and Television Festival of Ouagadougou, in Burkina Faso), international film festivals on the African continent (founded from the late 1970s, such as the Durban International Film Festival in South Africa), African film festivals outside of the continent (founded from the late 1970s, such as the New York African Film Festival), and international film festivals outside the continent that have particular curators and/or programs dedicated to films by Africans (where this specific focus on Africa has emerged since the late 1990s, such as at the Dubai International Film Festival).

Other typologies worthy of analysis cut across this map, however. For example, in the category of international film festivals on the African continent (which have proliferated at a rapid rate since 2000), there are markedly distinct curatorial visions and practices. Where many (African) filmmakers feel that the Durban International Film Festival, with its Talent Campus and FilmMart (a film market) modeled on those of "A-list" film festivals, offers the most significant professional opportunities to filmmakers of all the festivals on the continent, other festivals bring a different version of the international and global into play to distinct ends. For example, the FiSahara Film Festival (founded in 2004), which is the only annual film festival in the world to take place in a refugee camp (Dakhla, in Algeria), has as its aim mobilizing international activism on behalf of a specific, local cause: the claim of the Sahrawi people to the Western Sahara, which was annexed from them by Morocco in 1975. The arrival in 2013 of a completely new kind of film festival related to African film - the first Online South African Film Festival - unsettles festivals' typical relationship to live publics and suggests further productive typologies for analysis of both film festivals and online, digital platforms and their respective curatorial approaches to films by Africans. Initiated by the video-on-demand (VOD) platform AfricaFilms.tv, presided over by veteran South African filmmaker Ramadan Suleman, and curated by Lesedi Moche (former director of the Encounters Documentary Film Festival in South Africa), the first Online South African Film Festival ran from July 18 to September 22, 2013, and offered viewers the chance to rent or buy 150 rarely accessible South African films and television series.

The impulse behind much of the African video-movie scholarship is the same as the impulse behind the study of film festivals, a relatively new academic subfield, and one that seeks to rematerialize film studies, albeit from an entirely different angle to the

see Matthias Krings and Onookome Okome, eds., Global Nollywood: The Transnational Dimensions of an African Video Film Industry (Bloomington: Indiana University Press, 2013); Garritano, African Video Movies, 7.

3 See Lindiwe Dovey, Curating Africa in the Age of Film Festivals (New York: Palgrave Macmillan, forthcoming). 
video scholarship. ${ }^{4}$ My current research aims to take up the gauntlet presented by the scholars of African video, by looking not at the video industries themselves but at those entities - film festivals - that have frequently been positioned as their polar opposite, because of their assumed investment in concepts such as high art and quality film. ${ }^{5}$ When Senegalese filmmaker Moussa Sene Absa told me in an interview that "without festivals, African cinema wouldn't exist," he was referring to that broad group (though not a genre) of films made by Africans that is best defined through analysis of the curatorial, exhibition, distribution, and reception architecture of film festivals. ${ }^{6}$ The ambiguous nature of Absa's statement, which can be read either as an endorsement or as a critique of the role film festivals have played in producing certain kinds of African cinema over the years, raises the question not solely of which specific films have been selected for and lauded at festivals but also of the specters, shadows, and exclusions of festivals' curatorial and canon-making processes - what Arjun Appadurai resonantly calls the "traffic in criteria." After all, as codirector of the Toronto International Film Festival Cameron Bailey says, "Festivals have multiplied and spread to become the single most important arbiter of taste in cinema-more important than scholars, or critics, more important even than film schools." 8 In many ways, film festivals have been the unacknowledged enablers and mediators of scholarship in the field of African cinema (as opposed to the broader field of African screen media), shaping canons and making certain films accessible to scholars and others not. They are, for this reason, an important heuristic device for exploring not only the mass media of Nollywood movies or television shows such as Big Brother Africa (MNet, 2003-) but also the "small media" that rarely enjoy mainstream distribution and exhibition outside of festivals.

My contention is that by analyzing African screen media "through the eye" of film festivals and their audiences, we can sharpen our critical understanding of certain kinds of film cultures within and beyond Africa and of how particular canons of African cinema and cinema tout court are constantly being reframed for and by specific, situated publics. Film festivals are a heuristic device for the analysis of two related practices, then: first, the selection and contextualization of certain films by curators; and second, the responses of actual (rather than hypothetical) spectators to these films. I want to focus first on several examples of the role of the curator in shaping what comes to constitute "African film" at any particular moment. Through a major program of more than seventy African films at the 2010 International Film Festival of Rotterdam (IFFR), curators Alice Smits and Lee Ellickson questioned the common assumption in the field that Ousmane Sembene is the only "father of African cinema"; by showing

4 For a constantly updated bibliography of scholarship on film festivals, see Skadi Loist and Marijke De Valck's Film Festival Research Network Bibliography, at http://www.filmfestivalresearch.org/index.php/ffrn-bibliography/. Dina Iordanova has also been a pioneer in this field, and her series of (co)edited books on film festivals published by St. Andrews Film Studies are an important resource.

5 See, e.g., Ramon Lobato, Shadow Economies of Cinema: Mapping Informal Film Distribution (London: BFI, 2012).

6 Moussa Sene Absa, interview by author, Tarifa African Film Festival, May 25, 2010.

7 Sarah Nuttall, introduction to Beautiful/Ugly: African and Diaspora Aesthetics (Durham, NC: Duke University Press, 2006), 13.

8 Jeffrey Ruoff, Coming Soon to a Festival near You: Programming Film Festivals (St. Andrews, Scotland: St. Andrews Film Studies, 2012), iv. 
films made before Sembene's Borom sarret (1963) — such as Gadalla Gubara's Song of Khartoum (1955) and Momar Thiam's Sarzan (1963) - they suggested that conventional African film history should be prized open for reassessment. A similar impulse toward the rewriting of African film history occurred at the Tenth African Film Festival of Córdoba in Spain in October 2013 in a program strand called "Diez fragmentos de un discurso amoroso (africano)" ("Ten fragments of an [African] discourse on love"), curated by Marion Berger. The program included newer films, such as Jocelyne Saab's sensual feature film Dunia (2005), and films considered African film "classics" — such as Touki bouki (1973), Muna moto (1975), and Tilaï(1990). A printed flyer that accompanied the program reflected on its origins as follows:

Many festivals tend to valorize African films on account of their social, political, or historical dimensions, conditioning the Western spectator to expect didactic content. . . . With this retrospective, we are not trying to elaborate an anthropological analysis of practices of love or manifestations of desire in Africa. Rather, we wish to affirm, across this subjective selection of films with which we feel a special affinity, an African discourse of love. . . Ten sessions of cinema, ten fragments in which the filmmakers conjugate the verbs of love, play with romantic ideals and fashion a visual map of this universal sentiment. $^{9}$

In these poetic and affective terms, Berger shaped the mode in which first-time (mostly Spanish) viewers of these films would approach them. She argued that certain films have been burdened by a discourse claiming the politicized nature of African cinema and that those films are overdue a re-viewing from new angles. Of course, one could take issue with the curatorial approaches of Smits, Ellickson, and Berger. In an interview at the 2010 IFFR, Momar Thiam told me that Sembene deserves the title "father of African cinema" - not because he was the first African to make a film in sub-Saharan Africa (which he was not), but for the specific vision he brought to his filmmaking. ${ }^{10}$ One could also raise questions about the extent to which romantic love is, and has been, a "universal sentiment" and whether Berger's program at Córdoba was involved in rewriting African film history or in helping to hasten its steady incorporation into the generic field of world cinema. Such questions and challenges are part and parcel of the curatorial approach for which I am advocating, however; they insist on the subjective, dynamic, and - crucially - public nature of any act of curation, and the necessity of curators making explicit their criteria of judgment.

The shared inspiration behind Berger's program and recent work in African screen media studies, which has sought to highlight the pleasures rather than politics of films by Africans, shows that the practices of curating and scholarship do not have to operate in competition but might chart a reciprocal relationship in the future. ${ }^{11}$ My own work with African film over the past thirteen years has consistently combined these two modes - curating and academic research - since I enjoy making the more abstract

9 My translation from Spanish.

10 Momar Thiam, interview by author, International Film Festival of Rotterdam, February 3, 2010.

11 See, e.g., Alexie Tcheuyap, Postnationalist African Cinemas (Manchester, UK: Manchester University Press, 2011). 
arguments in my scholarship available to a broader audience through my curating and in turn reflecting on my curatorial practice in my scholarship. ${ }^{12}$ Furthermore, as I have argued elsewhere, teaching, too, needs to be seen as a form of curatorial work (though a far less public form of curating than film festivals demand), because the creation of syllabi inevitably involves selecting and contextualizing certain films and readings to the exclusion of others. ${ }^{13}$ Dina Iordanova goes even further, arguing that, in a world in which films are increasingly moving online, "scholars now resemble curators and guides; no longer helping students discover cinema itself, but mostly assisting them in connecting, comparing, and making things meaningful in cinema's relation to history, aesthetics, and politics." 14

However, we must not forget that other side of the curatorial coin: spectatorship. As media ethnographers have emphasized, films are material objects that have social lives, and their meanings constantly change as they circulate through distinct contexts. ${ }^{15}$ If we are serious about incorporating broader publics into our scholarship, then we need to include a "distribution-centred model of film studies" that asks, "Who is the audience? How are they constructed as such? What are the material limits that determine which texts are available to which audiences?"16 And, as Karin Barber has asked, what are the interpretive repertoires of these audiences, and how do they refashion the meanings of films? ${ }^{37}$ African screen media scholarship remains relatively impoverished on the question of spectatorship. ${ }^{18}$ Furthermore, as Harrow has pointed out, the "irony . . . is that when popular critical approaches are employed, audience perspectives are recorded that would be considered naïve by academic or scholarly critics."19 Such "naïve" perspectives are not necessarily the case, however, and film festivals are one of those sites at which scholars can directly access the diverse ways in which spectators negotiate the meanings of films - through observing Q\&As or through more directed control-group discussions and interviews.

The most important lesson I have learned through my field research with spectators at film festivals is that - as Olivier Barlet puts it - the "African audience is anything but homogeneous." 20 We cannot simply argue, as Harrow does, that "Nollywood . . .

12 See, e.g., Lindiwe Dovey, "New Looks: The Rise of African Women Filmmakers," Feminist Africa 16 (2012): 18-36; Dovey, Curating Africa.

13 Lindiwe Dovey, "Curating Africa: Teaching African Film through the Lens of Film Festivals," Scope: An Online Journal of Film and Television Studies 26 (2014): 6-9.

14 Dina lordanova, "Instant, Abundant, and Ubiquitous," Cineaste 39, no. 1 (Winter 2013): 49.

15 Faye Ginsburg, Lila Abu-Lughod, and Brian Larkin, eds., Media Worlds: Anthropology on New Terrain (Oakland: University of California Press, 2002).

16 Lobato, Shadow Economies of Cinema, 6.

17 Karin Barber, "Preliminary Notes on Audiences in Africa," Africa 67, no. 3 (1997): 347-362.

18 See, however, Minou Fuglesang, Veils and Videos: Female Youth Culture on the Kenyan Coast (Stockholm: Gotab, 1994); Brian Larkin, "Indian Films and Nigerian Lovers: Media and the Creation of Parallel Modernities," Africa 67, no. 3 (1997): 406-440; Laura Fair, "They Stole the Show! Indian Films in Coastal Tanzania, 1950s-1980s," Journal of African Media Studies 2, no. 1 (2010): 91-106; Krings and Okome, Global Nollywood, 179-284.

19 Kenneth Harrow, "An Afromodern Cinema: Review of Global Nollywood: The Transnational Dimensions of an African Video Film Industry, Edited by Matthias Krings and Onookome Okome," Journal of African History 55, no. 2 (2014): 286. 
is the answer to African culture's quest for a viable economic basis that rests upon an African audience and its taste." 21 As popular as Nollywood may be across Africa and in the diaspora, film taste is as diverse as are Africans themselves. This point became overwhelmingly apparent to me at the 2010 Kenya International Film Festival, when I brought twenty-two young women from Kibera, Nairobi's largest "slum," to the Alliance Française in downtown Nairobi (the festival's headquarters) to see Soul Boy (Hawa Essuman, 2010), a film shot in Kibera with Kiberans and which had won the Dioraphte Award (an audience prize) at its world premiere at the 2010 IFFR earlier that year. The young women were, at the time, students at the Kibera Girls Soccer Academy (KGSA), a high school founded in Kibera in 2006 by Abdul Kassim. ${ }^{22}$ After the screening, I held two separate, two-hour discussions with the women with the help of a colleague, Julie MacArthur. ${ }^{23}$ Before the discussions, I had assumed that the young women would respond most enthusiastically to "popular" African video movies and not to an acclaimed "festival" film such as Soul Boy, given what I had read in African screen media scholarship about the influence of class and location on spectatorship in Africa. The women, however, brought a conventional notion of aesthetic quality to bear on their interpretation of Soul Boy in relation to the films that they are more accustomed to watching-Mexican soap operas, Nigerian video movies, Bollywood films, kung fu films, and cheaply produced Kenyan horror films. Of the latter, one respondent said: "The cameras are shaking. . . Instead of enjoying you are crying. The light is so bad - there is just darkness. The quality of the movies is just down." Similarly, of Nigerian video movies, one respondent said: "They don't do auditions there in Nigeria. They just tell people, 'Come and act!' . . That shows that they are not even close to being creative." Of Soul Boy, in contrast, one respondent said: "I've seen many Kenyan movies. That kind of creativity did not exist. . . And the creativity of putting cameras on the railway line [in Soul Boy], I've never seen that." Notably, creativity was the term the women constantly used to distinguish Soul Boy from other films, and it is a term that they made me realize is far more appropriate than aesthetic quality, because it conjoins the look and sound of a film with the decisions of the director, crew, and actors. Although there was debate about specific elements of the film (emphasizing the heterogeneity of taste), there was also remarkable consensus about the creative value of Soul Boy. What the discussions revealed, then, is that there is no homogeneous "African audience" with homogeneous taste. As African screen media scholars, we might think, erroneously, of the category of "aesthetic quality" as something produced exclusively at film festivals, whereas it was a criterion by which the young women of the KGSA were judging films, even though they do not often have access to festivals. Further research I co-conducted in the context of the new Slum Film Festival in Kibera and Mathare also revealed that Soul Boy is one of the most popular films in this context, a "cross-over" film that has found validation on the international film festival

21 Kenneth Harrow, Trash: African Cinema from Below (Bloomington: Indiana University Press, 2013), 6; my emphasis.

$$
\text { e }
$$
To test the similarities and differences of the res
eleven, and each of us recorded our discussions. 
circuit as well as within a community generally marginalized from this circuit, thereby complicating any easy dichotomy of festival cinema and popular film. ${ }^{24}$

Studying African screen media "through the eye" of film festivals should inspire us, as scholar-curators, to reflect on the subjectivity and volatility of film taste and on our own criteria of judgment. Doing so will also bring us into contact with diverse, actual spectators of African films, and of films in Africa, compelling us to move beyond interpretive repertoires limited to the "ivory towers" of university spaces. One might argue that access to film festivals and to such "ordinary" spectators paradoxically requires the "ivory tower" funding of these same university spaces. More positively, however, we could argue that making film festivals one of our sites of research will privilege scholarship emerging from the African continent itself (where the majority of these festivals take place, and where most African spectators are of course located); will encourage new avenues for audience research within the (arguably more accessible) digital sphere (through online film festivals and audience responses to festival films through social media); and will inspire more collaborative research, given the multidimensional and complex nature of festivals.

24 Lindiwe Dovey, Joshua McNamara, and Federico Olivieri, “'From, by, for': Nairobi's Slum Film Festival, Film Festival Studies, and the Practices of Development," Jump Cut 55 (2013), http://ejumpcut.org/currentissue/DoveySFFNai robi/index.html.

I would like to acknowledge the generous support of the Philip Leverhulme Prize and SOAS, University of London, which has helped to enable the research on which this article is based. 